Mini-Review

\title{
The effects of hydrogymnastics on functional autonomy in elderly women: a meta-analysis
}

\author{
Ravini de Souza Sodré ${ }^{1,2,3}\left(\mathbb{D}\right.$, Mariana I. Matos ${ }^{1,2}\left(\mathbb{D}\right.$, Glória de Paula Silva ${ }^{1,2,3}$, \\ Frederico O. Meirelles ${ }^{2}$, Priscila dos Santos Bunn ${ }^{1,2,4} \mathbb{0}$, Elirez B. da Silva ${ }^{1,2} \mathbb{C}$ \\ ${ }^{1}$ Universidade Estadual do Rio de Janeiro, Instituto de Educação Física e Esportes, Programa de Pós-graduação \\ em Exercicio e Ciências do Esporte, Rio de Janeiro, RJ, Brasil,; ${ }^{2}$ Menbro do Grupo de Pesquisa em Ciências do \\ Esporte e da Saúde, GPCES, Rio de Janeiro, RJ, Brasil; ${ }^{3}$ Universidade Castelo Branco, Grupo de Pesquisa em \\ Exercício Físico e Promoção da Saúde, Rio de Janeiro, RJ, Brasil; ${ }^{4}$ Centro de Educação Física "Almirante Adalberto \\ Nunes”, Laboratório de Pesquisas em Ciências do Exercício, Marinha do Brasil, Rio de Janeiro, RJ, Brasil
}

\begin{abstract}
Aim: To Verify the effects of hydrogymnastics on functional autonomy in elderly women. Method: In November 2018, a systematic review of the literature was performed in the databases MEDLINE, SciELO, LILACS, PEDro, Cochrane, Web of Science, SPORTDiscus, SCOPUS e CINAHL. Two independent researchers selected randomized clinical trials, which evaluated the effects of hydrogymnastics over healthy elderly women performance on functional tests performance on functional tests. From each study they selected the number of participants in both experimental and control groups (EG and CG), age, intervention protocol, mean and standard deviation before and after the intervention for the following variables: legs and biceps muscular strength, posterior muscle chain extensibility, and agility - all of which compose the functional autonomy on Rikli and Jones test. We analyzed the methodological quality and the risk of bias through the Jadad Scale and the Cochrane tool respectively. We performed the data analysis through the random effects model and the mean difference between CG and EG. The analysis of the publication bias was done with Egger Test. Results: We found a total of 887 studies in the aforementioned databases, and five randomized clinical trials were included in the present meta-analysis. In spite of the evidence level is very low, the hydrogymnastics promoted an increase in agility and leg muscle strength in elderly women.
\end{abstract}

Keywords: exercise; aging; aquatic activity

\section{Introduction}

The aging process encompasses multiple dimensions which embrace a series of biological, psychological, social and cultural ${ }^{1,2}$ aspects. All of which leads to a natural process of progressive losses, especially of muscle mass and flexibility ${ }^{3,4}$. A sedentary lifestyle can be an aggravating factor, causing a decrease of physical-functional performance. In light of this, functional autonomy has been the subject of many studies over the last years for it relates to physical independence and the ability to execute daily activities by elderly people ${ }^{7-9}$.

Given the fact that the number of seniors is bound to triple by $2050{ }^{10}$ a change in public policies will be mandatory. However, the population studies that have observed the senior population present major limitations that interfere in the quality of life, and the functional autonomy is decisive in determining the independence in the daily life $\mathrm{e}^{11-15}$.

Regular physical exercising seems to contribute to the improvement and/or maintenance of functional autonomy in seniors. Aquatic exercises, hydrogymnastics specifically, provide postural stability due to the hydrostatic pressure ${ }^{16,17}$, reduction of joint overload, owing to the thrust force and water resistance, as a consequence of the viscosity ${ }^{14}$.

Taking the benefits into consideration, it is possible to apply the practice of hydrogymnastics as an alternative modality for physical fitness ${ }^{18,19}$. The regular practice of this exercise warms up joints and muscles at the same time. It is also responsible for increasing the levels of muscle force, aerobic capacity, physical resistance, and flexibility ${ }^{20}$.

Therefore, the objective of the present meta-analysis was to verify the effects of hydrogymnastics over elderly women functional autonomy.

\section{Materials and Method}

Writing, protocol, and recording

The present work was based on PRISMA - Preferred Reporting Items for Systematic Reviews and Meta-Analysis ${ }^{21}$ and recorded on the International Prospective Register of Systematic Reviews (PROSPERO) under the number CRD42018093299.

\section{Inclusion criteria of the studies}

We included experimental, controlled and randomized studies with women over 60 years old, comparing the ones who practiced hydrogymnastics o a sedentary control group. 


\section{Search strategy}

A systematic search without time or language filters was performed in April 2019 on the following databases MEDLINE(US National Library of Medicine), SciELO (Scientific Electronic Library Online), LILACS (Latin American and Caribbean Literature in Health Sciences), PEDro (Physiotherapy Evidence Database), SPORTDiscus, CINAHL(Cumulative Index to Nursing and Allied Health Literature), SCOPUS e Web of Science. The search phrases were developed with the Boolean logic operators "OR" between synonyms and "AND" between descriptors (Appendix 1). Although the terms "hydrogymnastics" and "functional capacity" were not identified on the descriptors DeCS and MeSH, they were inserted in the main descriptors as search strategy because they have appeared in several previous studies on the theme. We researched reference lists and other sources to find further studies.

We performed a preliminary analysis of the titles and abstracts that met the inclusion criteria. Then, we read the full version of the ones that were more relevant for the present work.

\section{Methodological quality evaluation}

We chose to use the Jadad scale, applied by two independent and qualified researchers. We requested a third researcher to decide on discordant assessments. We considered the following methodological criteria: 1a); the description of the study as randomized; 1b) the randomization was properly performed; 2a) it was a double-bind trial; $2 \mathrm{~b}$ ) the blinding was properly performed; 3 ) description of the sample loss. In case the items $1 \mathrm{a}, 2 \mathrm{a}$ and 3 were met, the study got 1 point per item. If the items $1 \mathrm{~b}$ and $2 \mathrm{~b}$ were observed, the study got another point per item. Moreover, in case of items $1 \mathrm{~b}$ and $2 \mathrm{~b}$ were not met, it caused the study to lose 1 point regarding items $1 \mathrm{a}$ and $2 \mathrm{a}$, respectively.

\section{Risk of bias analysis}

Two independent and experienced evaluators analyzed the risk of bias in each study included in this meta-analysis and a third researcher evaluated the discordant assessments. We used the Cochrane Collaboration too $^{23}$ to assess the risk of bias in randomized clinical trials (2005-2007), available for download at http://ims.cochrane. org/revman/downloador online: http://cochrane-handbook.org.

\section{Data collection process}

We extracted the following data of the selected studies: number of participants of experimental and control groups (n), age, intervention protocol, measurement of the functional autonomy.

\section{Data analysis}

We used the program Review Manager 5.3 - available at http:// tech.cochrane.org/revman- to analyze the following data: variables of biceps and legs muscular force, agility, and posterior muscle chain extensibility, which compose the functional autonomy in the Rikli and Jones test. The variable was continuous, the statistic method was the inverse-variance, and the analysis model was the random effect. The effect measure was the difference between the means with a $95 \%$ confidence interval from the studies and the meta-analysis and the distribution of the studies by the weight of each one in the meta-analysis. We analyzed the risk of publication bias both qualitatively, with funnel plot, and quantitatively, with Egger test, on Stats Direct Software, version 3.

\section{Assessment of evidence level}

Two independent researchers used the tool Grading of Recommendations Assessment, Development and Evaluation Approach (GRADE) to assess the level of evidence for each outcome $\mathrm{e}^{24-27}$. There are four classification levels to assess the quality of evidence: high, moderate, low and very low. The controlled randomized studies start from high quality of evidence whereas the observational studies start from low quality of evidence. Five aspects can lower the quality of evidence (methodological limitations), inconsistency, indirect evidence, inaccuracy and publication bias) and three aspects can increase the quality of evidence (effect size, dose-response gradient and confusion factor ${ }^{24-27}$.

\section{Results}

Figure 1 - Flowchart of the included studies in the meta-analysis

Table 1 - Data extracted from included studies

Figures: 2,3,4,5 - Forest Plot

Table 2 - Methodological quality of the studies analyzed through the Jadad Scale

Table 3 - Risk of Bias analysis through the Cochrane Collaboration Tool

Figures: 6,7,8,9 - Funnel plot

Table 4 - Level of evidence of the meta-analysis, according to the Grading of Recommendations Assessment, Development, and Evaluation Approach (GRADE).

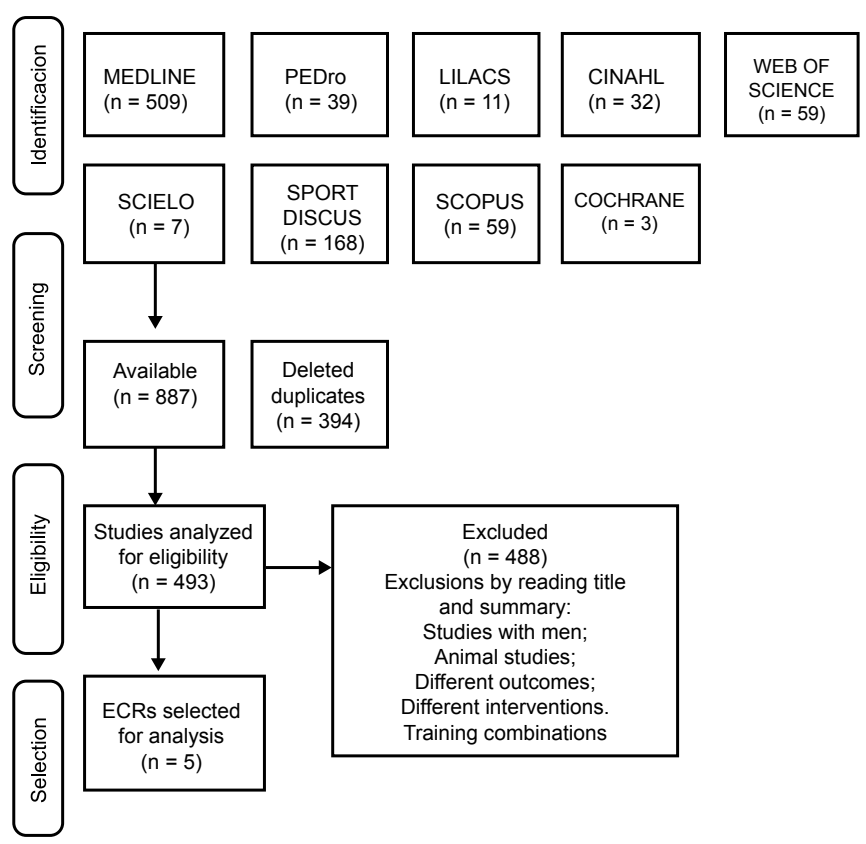

Figure 1. Flowchart of the selected studies for the meta-analysis 
Table 1. Data extracted from included studies

\begin{tabular}{|c|c|c|c|c|c|c|c|}
\hline \multirow[t]{2}{*}{ Author / year } & \multirow[t]{2}{*}{$\begin{array}{c}\text { Groups } \\
\text { (n) }\end{array}$} & \multirow[t]{2}{*}{$\begin{array}{c}\text { Age } \\
\text { (years) }\end{array}$} & \multirow[t]{2}{*}{ Intervention protocol } & $\begin{array}{c}\text { Sit and stand up } \\
\text { (rep) }\end{array}$ & $\begin{array}{c}\text { Arm Flexion } \\
\text { (rep) }\end{array}$ & $\begin{array}{l}\text { Sit and reach } \\
(\mathrm{cm})\end{array}$ & $\begin{array}{l}\text { Sitting, walk } \\
2,44 \mathrm{~m}, \text { go back } \\
\text { and sit(s) } \\
\end{array}$ \\
\hline & & & & $\mathbf{x} \pm \mathbf{d p}$ & $\mathbf{x} \pm \mathbf{d p}$ & $\mathbf{x} \pm \mathbf{d p}$ & $\mathbf{x} \pm \mathrm{dp}$ \\
\hline $\begin{array}{l}\text { Alves et al. } \\
2004(28)\end{array}$ & $\begin{array}{l}\mathrm{GE}=30 \\
\mathrm{GC}=30\end{array}$ & $\begin{array}{l}\mathrm{GE}=78 \pm 3 \\
\mathrm{GC}=79 \pm 5\end{array}$ & $\begin{array}{l}24 \text { sessions of } 45 \text { minutes } \\
2 \text { times a week, } 1 \text { minute of } \\
\text { execution per exercise }\end{array}$ & $\begin{array}{c}\mathrm{GE}=14,9 \pm 1,8^{*} \\
\mathrm{GC}=8,5 \pm 1,7\end{array}$ & $\begin{array}{l}\mathrm{GE}=21,6 \pm 2,8^{*} \\
\mathrm{GC}=10,5 \pm 2,7\end{array}$ & $\begin{array}{l}\mathrm{GE}=5,2 \pm 9,20^{*} \\
\mathrm{GC}=-5,0 \pm 11,3\end{array}$ & $\begin{array}{l}\mathrm{GE}=5,8 \pm 1,0^{*} \\
\mathrm{GC}=7,1 \pm 1,5\end{array}$ \\
\hline $\begin{array}{l}\text { Bocaliniet al./ } \\
2008(29)\end{array}$ & $\begin{array}{l}\mathrm{GE}=27 \\
\mathrm{GC}=20\end{array}$ & $\begin{array}{l}\mathrm{GE}=64 \pm 1 \\
\mathrm{GC}=63 \pm 1\end{array}$ & $\begin{array}{c}36 \text { sessions of } 60 \text { minutes } 3 \\
\text { times a week, with series of } 10 \\
\text { to } 15 \text { repetitions and intensity of } \\
70 \% \text { of the FC }\end{array}$ & $\begin{array}{c}\mathrm{GE}=37 \pm 3^{*} \\
\mathrm{GC}=23 \pm 1\end{array}$ & $\begin{array}{l}\mathrm{GE}=25 \pm 1^{*} \\
\mathrm{GC}=21 \pm 2\end{array}$ & $\begin{array}{l}\mathrm{GE}=36 \pm 2 * \\
\mathrm{GC}=23 \pm 2\end{array}$ & $\begin{array}{l}\mathrm{GE}=5,5 \pm 1 * \\
\mathrm{GC}=7,8 \pm 1,3\end{array}$ \\
\hline $\begin{array}{l}\text { Filho et al./ } \\
2016 \text { (a) (30) }\end{array}$ & $\begin{array}{l}\mathrm{GE}=24 \\
\mathrm{GC}=24\end{array}$ & $\begin{array}{c}\mathrm{GE}=65,42 \pm 5,31 \\
\mathrm{GC}=69,35 \pm 3\end{array}$ & $\begin{array}{c}36 \text { sessions of } 60 \text { minutes } 3 \\
\text { times a week }\end{array}$ & $\begin{array}{l}\mathrm{GE}=11,34 \pm 1,44 \\
\mathrm{GC}=11,43 \pm 1,66\end{array}$ & $\begin{array}{l}\mathrm{GE}=13,02 \pm 2,42 \\
\mathrm{GC}=12,58 \pm 2,32\end{array}$ & $\begin{array}{c}\mathrm{GE}=1,77 \pm 3,77 * \\
\mathrm{GC}=1,55 \pm 3,17\end{array}$ & $\begin{array}{l}\mathrm{GE}=6,46 \pm 1,05 \\
\mathrm{GC}=6,72 \pm 1,06\end{array}$ \\
\hline $\begin{array}{l}\text { Filho et al./ } \\
2016 \text { (b) (30) }\end{array}$ & $\begin{array}{l}\mathrm{GE}=24 \\
\mathrm{GC}=24\end{array}$ & $\begin{array}{c}\mathrm{GE}=65,42 \pm 5,31 \\
\mathrm{GC}=69,35 \pm 3\end{array}$ & $\begin{array}{l}72 \text { sessions of } 60 \text { minutes } 3 \\
\text { times a week with } 1 \text { minute of } \\
\text { execution per exercise and } 1 \\
\text { minute of recovery }\end{array}$ & $\begin{array}{l}\mathrm{GE}=11,66 \pm 1,57 \\
\mathrm{GC}=11,48 \pm 1,77\end{array}$ & $\begin{array}{c}\mathrm{GE}=14,31 \pm 3,71 * \\
\mathrm{GC}=12,68 \pm 3,31\end{array}$ & $\begin{array}{c}\mathrm{GE}=1,91 \pm 3,33^{*} \\
\mathrm{GC}=1,54 \pm 3,67\end{array}$ & $\begin{array}{c}\mathrm{GE}=6,24 \pm 1,12^{*} \\
\mathrm{GC}=6,72 \pm 1,08\end{array}$ \\
\hline $\begin{array}{c}\text { Tsourlouet al./ } \\
2006(31)\end{array}$ & $\begin{array}{l}\mathrm{GE}=12 \\
\mathrm{GC}=10\end{array}$ & $\begin{array}{c}\mathrm{GE}=69,3 \pm 1,9 \\
\mathrm{GC}=68,4 \pm 6,67\end{array}$ & $\begin{array}{l}72 \text { sessions of } 60 \text { minutes } 3 \\
\text { times a week with } 1 \text { minute of } \\
\text { execution for aerobic exercises } \\
\text { and } 2 \text { series of } 12 \text { to } 15 \\
\text { repetitions }\end{array}$ & NR & NR & $\begin{array}{c}\mathrm{GE}=23,60 \pm 1,08^{*} \\
\mathrm{GC}=22,87 \pm 2,4\end{array}$ & $\begin{array}{c}\mathrm{GE}=5,09 \pm 0,2 * \\
\mathrm{GC}=6,23 \pm 0,3\end{array}$ \\
\hline $\begin{array}{l}\text { Moreira et al/ } \\
2018 \text { (a) (32) }\end{array}$ & $\begin{array}{c}\mathrm{GE} 1=30 \\
\mathrm{GC}=30\end{array}$ & $\begin{aligned} \mathrm{GE} 1 & =62,8 \pm 9.1 \\
\mathrm{GC} & =68,1 \pm 7,9\end{aligned}$ & $\begin{array}{l}36 \text { sessions of } 40 \text { minutes } 3 \\
\text { times a week with } 1 \text { minute and } \\
30 \text { seconds of execution }\end{array}$ & $\begin{array}{c}\mathrm{GE} 1=13,8 \pm 2,9^{*} \\
\mathrm{GC}=11,1 \pm 2,7\end{array}$ & NR & $\begin{array}{c}\mathrm{GE} 1=4,9 \pm 7,8^{*} \\
\mathrm{GC}=-2,6 \pm 8,1\end{array}$ & $\begin{array}{c}\mathrm{GE} 1=7,6 \pm 1,3 \\
\mathrm{GC}=8,8 \pm 2,5\end{array}$ \\
\hline $\begin{array}{l}\text { Moreira et al/ } \\
2018 \text { (b) (32) }\end{array}$ & $\mathrm{GE} 2=30$ & $\begin{aligned} \mathrm{GE} 2 & =65,1 \pm 5,7 \\
\mathrm{GC} & =68,1 \pm 7,9\end{aligned}$ & $\begin{array}{l}36 \text { sessions of } 40 \text { minutes } 3 \\
\text { times a week with } 1 \text { minute and } \\
30 \text { seconds of execution (jumps) }\end{array}$ & $\begin{aligned} \mathrm{GE} 2 & =12,6 \pm 2,6^{*} \\
\mathrm{GC} & =11,1 \pm 2,7\end{aligned}$ & NR & $\begin{array}{c}\mathrm{GE} 2=7,1 \pm 7,6^{*} \\
\mathrm{GC}=-2,6 \pm 8,1\end{array}$ & $\begin{aligned} \mathrm{GE} 2 & =6,6 \pm 1,6^{*} \\
\mathrm{GC} & =8,8 \pm 2,5\end{aligned}$ \\
\hline
\end{tabular}

Filho: (a) evaluation at 12 weeks of intervention; (b) evaluation at 24 weeks of intervention;

Moreira: (a) conventional water aerobics evaluation; (b) water aerobics plyometric exercises for legs

$* \mathrm{P}<0.05$ in inter-group comparison after intervention; $\mathrm{NR}$ : did not report. $\mathrm{GE}=$ experimental group; $\mathrm{GC}=$ control group; rep = number of repetitions;

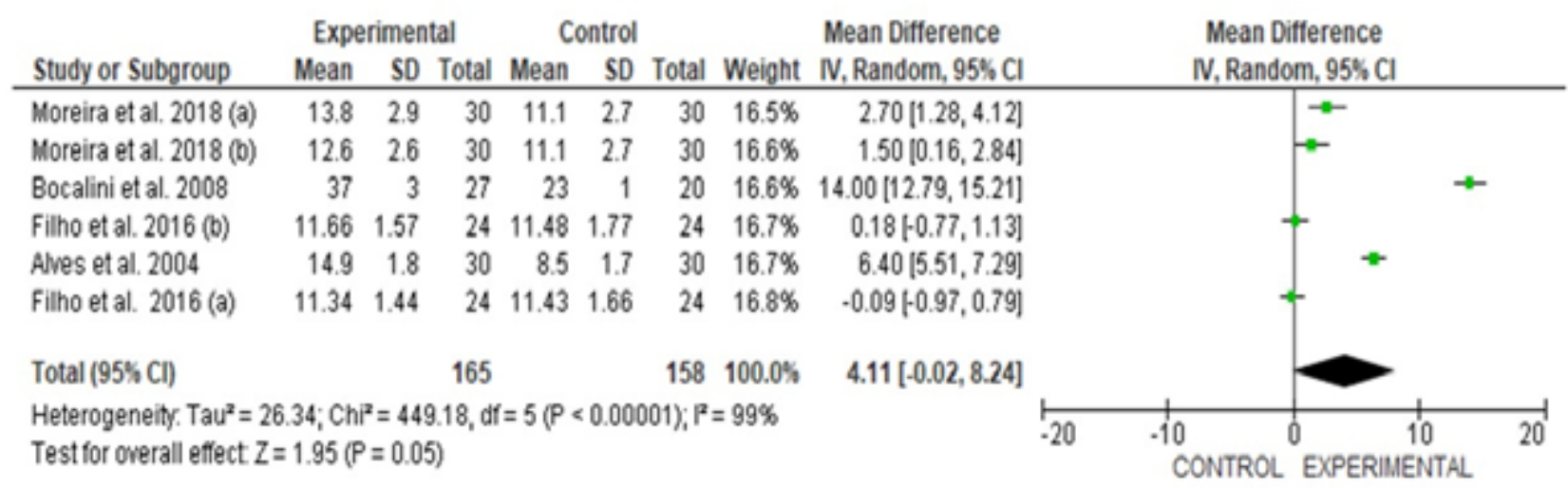

Figure 2. Forest plot of the six results of the four studies selected for leg strength and endurance measured by the "Sit and stand up" (repetitions) test in the Rikli Jones test battery. 


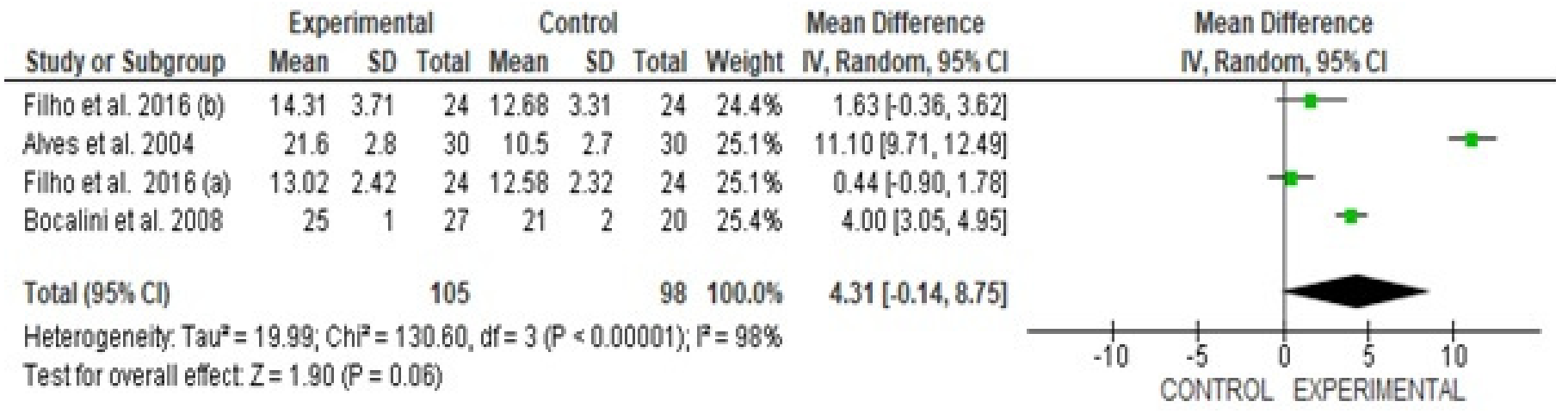

Figure 3. Forest plot of the four results of the three studies selected for brachial biceps strength and endurance measured by the Arm Flexion (repetitions) test in the Rikli Jones test battery.

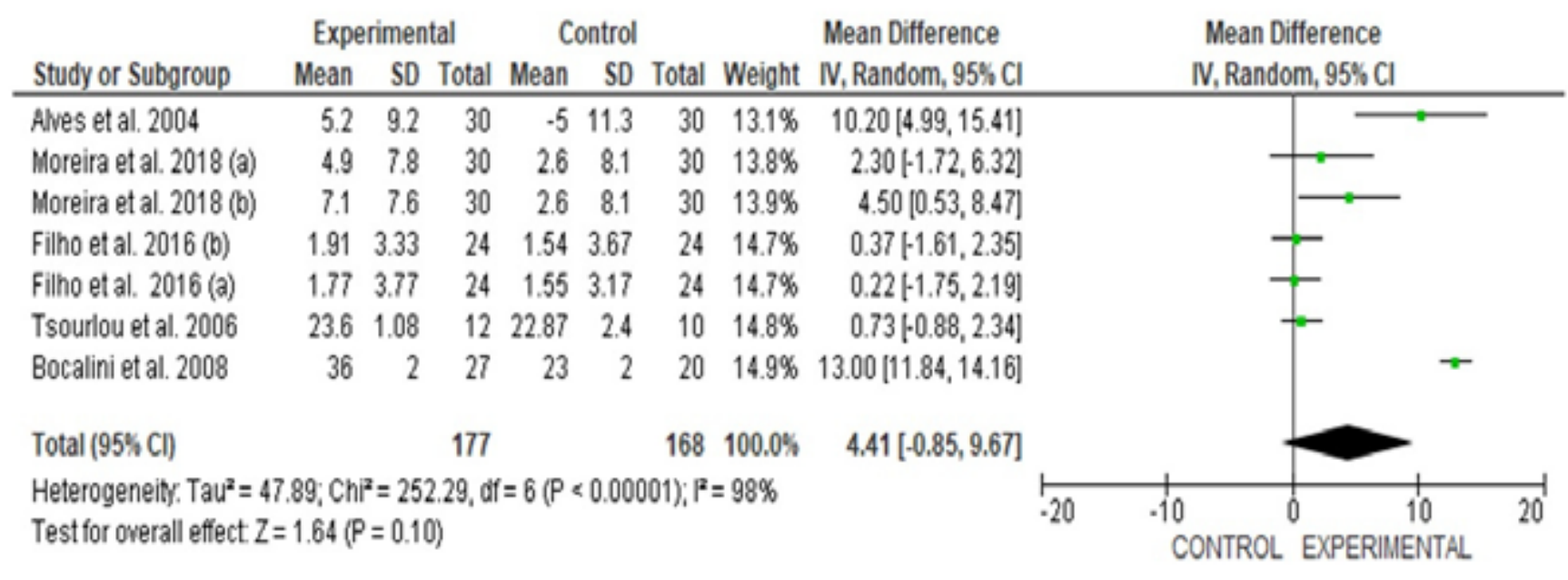

Figure 4. Forest plot of the seven results of the five studies selected for posterior muscle chain extensibility measured by the "Sit and Reach" test $(\mathrm{cm})$ in the Rikli Jones test battery.

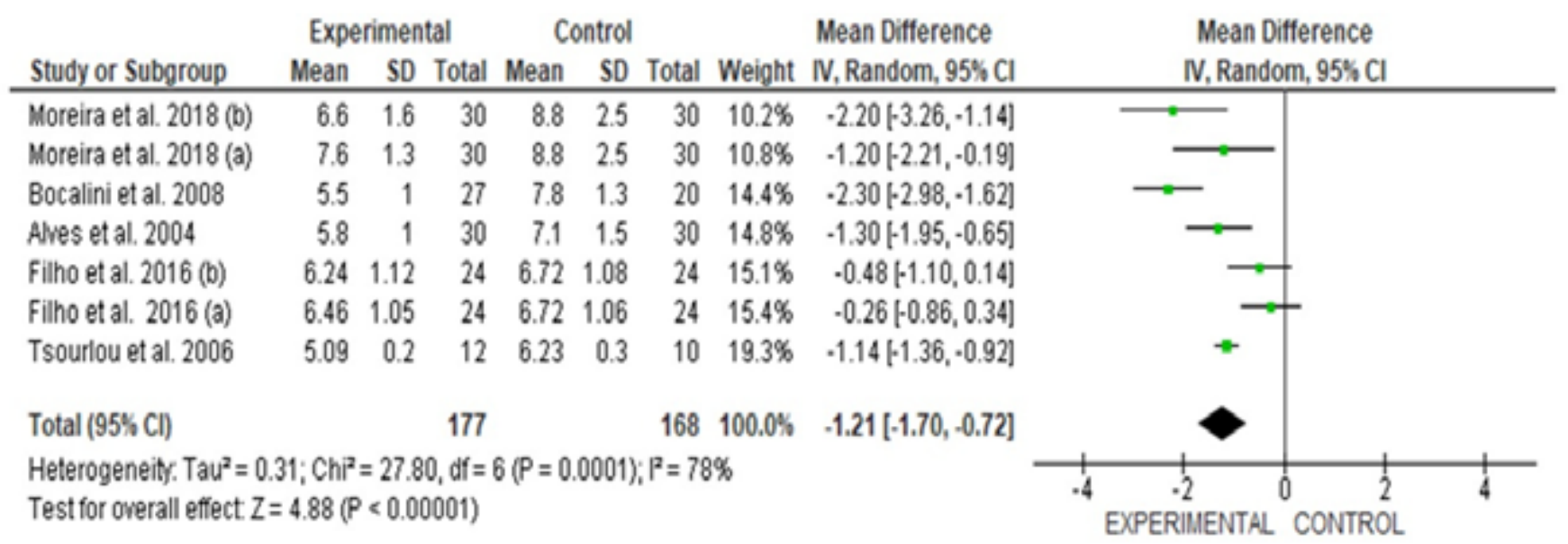

Figure 5. Forest plot of the seven results of the five studies selected for agility measured by the "Sitting, walk $2.44 \mathrm{~m}$ go back and sit" test (s) in the Rikli Jones test battery. 
Table 2. Methodological quality of the studies analyzed through the Jadad Scale (30)

\begin{tabular}{cccccc}
\hline Author & 1a & 1b & 2a & 2b & 3 \\
\hline Alves et al. $(2004)$ & YES & NOT & NOT & - & YES \\
Bocalini et al. $(2008)$ & YES & NOT & NOT & - & YES \\
Filho et al. $(2016)$ & YES & NOT & NOT & - & YES \\
Tsourlou et al. $(2006)$ & YES & NOT & NOT & - & YES \\
Moreira et al. $(2018)$ & YES & NOT & - & YES & 1 \\
\hline
\end{tabular}

Subtitle: 1a - Randomized study; 1b- Adequate randomization; 2a - Double-blind study; 2b - Proper blinding; 3- Description of sample loss

Table 3. Risk of Bias analysis through the Cochrane Collaboration Tool

\begin{tabular}{|c|c|c|c|c|c|c|c|c|}
\hline Author & Randomization & $\begin{array}{c}\text { Allocation of } \\
\text { randomization }\end{array}$ & $\begin{array}{l}\text { Blinding of } \\
\text { participants }\end{array}$ & $\begin{array}{c}\text { Blinding of } \\
\text { the evaluators }\end{array}$ & $\begin{array}{c}\text { Incomplete } \\
\text { Outcomes }\end{array}$ & $\begin{array}{c}\text { Report of Selective } \\
\text { outcome }\end{array}$ & $\begin{array}{c}\text { Other sources } \\
\text { of bias }\end{array}$ & Risk of bias \\
\hline Alves et al. (2004) & HIGH & HIGH & LOW & UNCERTAIN & LOW & LOW & LOW & HIGH \\
\hline Bocalini et al. (2008) & UNCERTAIN & UNCERTAIN & LOW & UNCERTAIN & LOW & LOW & LOW & UNCERTAIN \\
\hline Filho et al. (2016) & UNCERTAIN & UNCERTAIN & LOW & UNCERTAIN & LOW & LOW & LOW & UNCERTAIN \\
\hline Tsourlou et al.(2006) & LOW & UNCERTAIN & LOW & UNCERTAIN & LOW & LOW & LOW & UNCERTAIN \\
\hline Moreiraet al. (2018) & HIGH & UNCERTAIN & LOW & LOW & LOW & LOW & LOW & UNCERTAIN \\
\hline
\end{tabular}

Note: The items referring to the blinding of the participants were considered as low risk of bias, even when not explicit in the RCT, since the studies that use physical exercises as intervention cannot neutralize this bias.

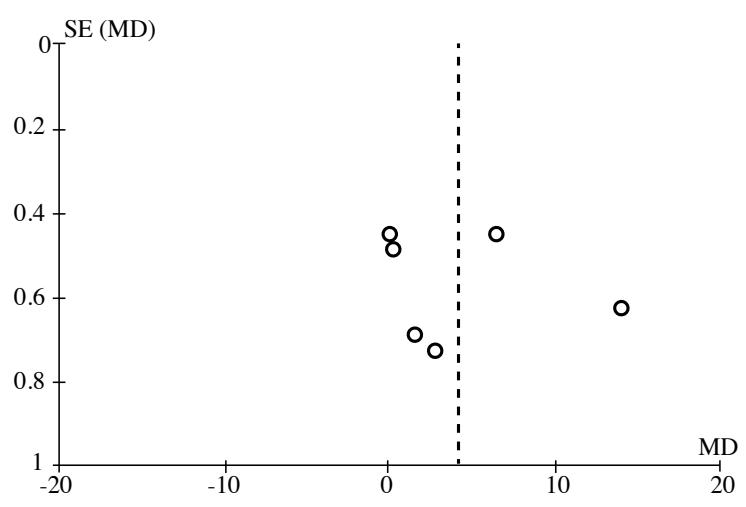

Figure 6. Funnel plot six results from the four selected studies for leg strength and muscular endurance measured through the "Sit and stand up" (repetitions) test from the Rikli Jones test battery The Egger test was performed with bias $=19,455,932(95 \% \mathrm{CI}=1.452238$ to 37.459626) and $\mathrm{P}=0.0399$.

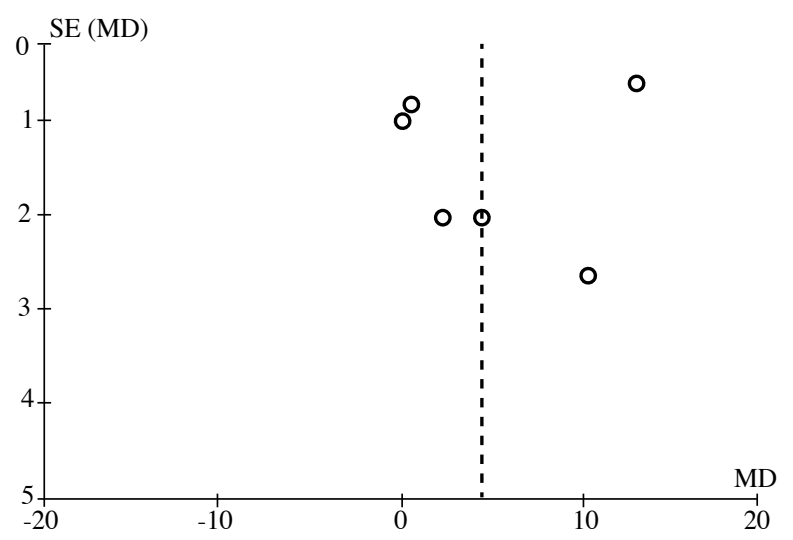

Figure 8. Funnel plot of the seven results of the five studies selected for the posterior muscle chain extensibility measured through the "Sit and Reach" (cm) test from the Rikli Jones test battery. The Egger Test was performed with bias $=10.164386(95 \% \mathrm{CI}=2.635451$ to 17.693321) and $\mathrm{P}=0.0178$.

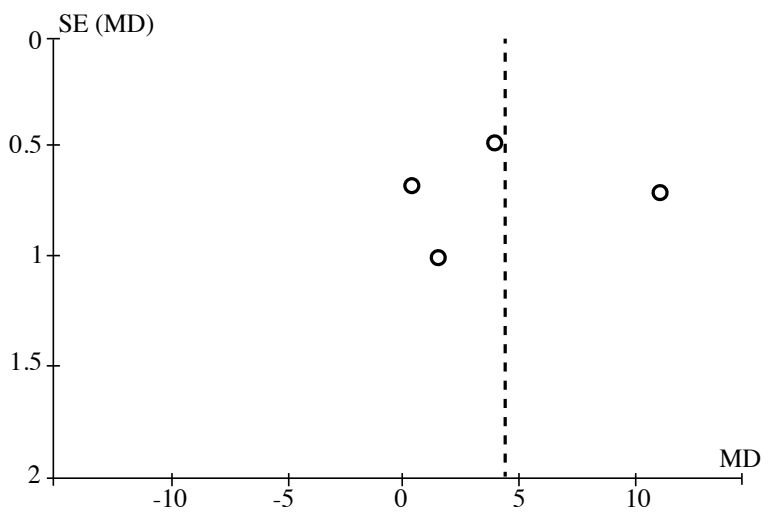

Figure 7. Funnel plot of the four results of the three studies selected for brachial biceps strength and endurance measured through the "Arm Flexion" (repetitions) test from the Rikli Jones test battery. Egger's test was performed with bias $=22.796396(95 \% \mathrm{CI}=16.748872$ to 28.843921) and $\mathrm{P}=0.0038$.

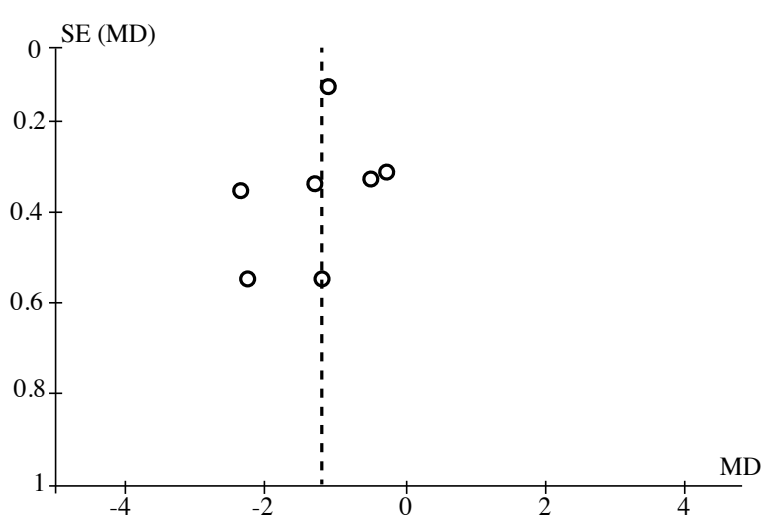

Figure 9. Funnel plot of the seven results of the five selected studies for agility measured through the "Sitting, walk $2.44 \mathrm{~m}$ go back and sit" test (s) from the Rikli Jones test battery. The Egger test was performed with bias $=-7.063103(95 \% \mathrm{CI}=-11.12332$ to -3.002886$)$ $\mathrm{P}=0.0066$. 


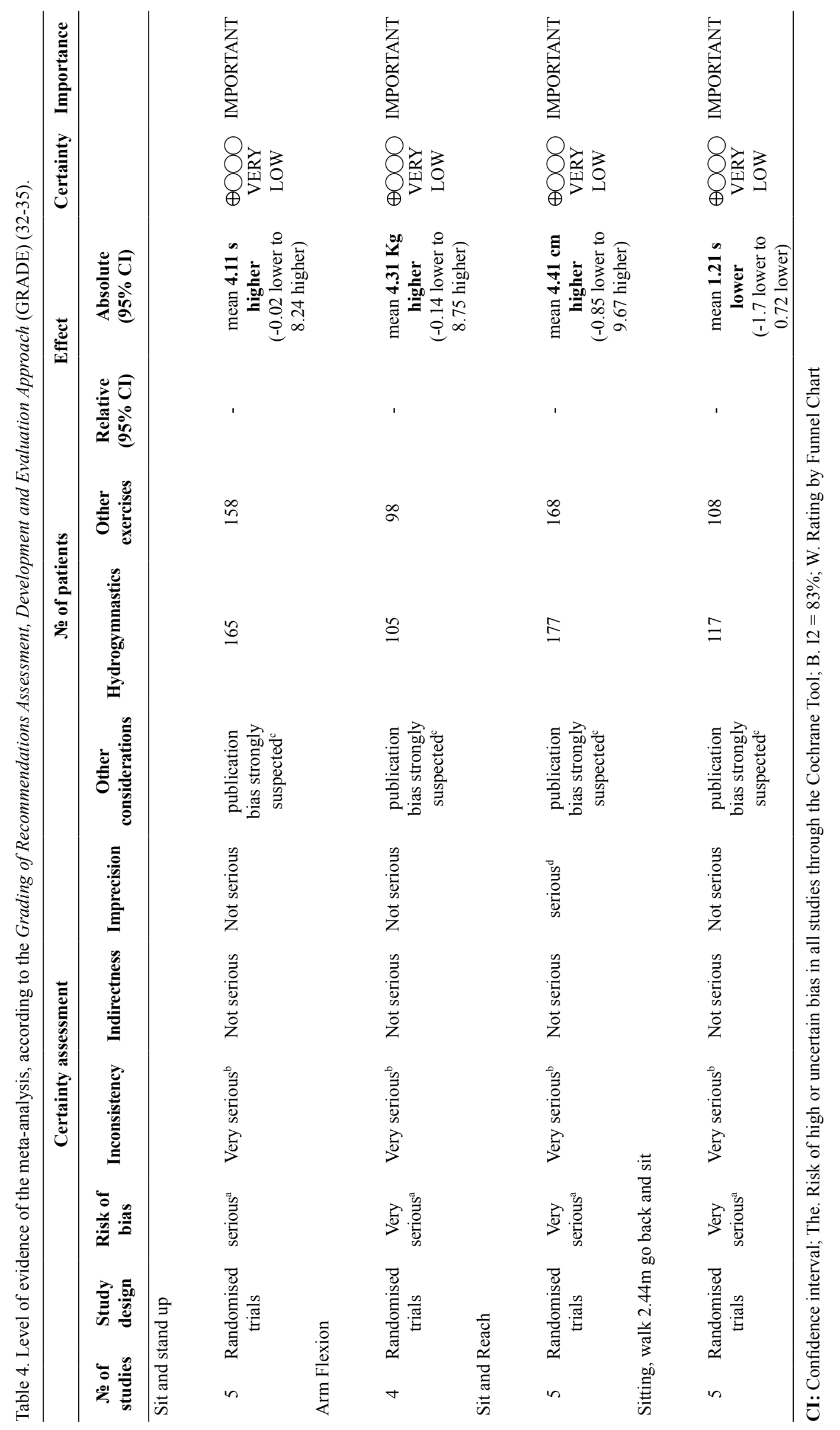




\section{Discussion}

The meta-analysis of the four controlled and randomized experiments showed that 177 of the elderly women who have practiced hydrogymnastics presented an average reduction of $-1,21(95 \% \mathrm{CI}=-1.70$ to -0.72$)$ seconds to cover $2.44 \mathrm{~m}$ on foot, which means a significant increase in agility (Figure 5). 165 of the elderly women who practiced hydrogymnastics performed $4.11(95 \% \mathrm{CI}=-0.02$ to 8.24$)$ more repetitions of sitting and standing up from a chair, which means a significant increase in leg strength and endurance (Figure 2). However, the biceps strength performance did not vary among the 105 elderly women who practiced hydro gymnastics and the 98 elderly women in the control group (Figure 3), the same occurred regarding the posterior muscle chain extensibility among 177 participants who practiced the activity and 168 of the control group (Figure 4).

The viscosity creates resistance through particle displacement while walking in the water. Thus, it is necessary to make a bigger effort to walk and at the same time, it is 790 times more difficult to walk in water than on land due to the counter-resistance ${ }^{33,34}$. Therefore, when we compare an individual walking in the water to someone walking on land, at the same execution speed, the reduced resistance caused by the airflow will result in a lower movement time in comparison to the water ${ }^{33,34}$. Consequently, exercises like walking, running and lateral movement, practiced at least 2 to 3 times a week, for 12 weeks of intervention, maybe the reason why the elderly women assessed in the test "sitting, walk $2.44 \mathrm{~m}$, go back and sit" (Figure 5) experimented an increase in agility.

Such increase in agility (Figure 5) is relevant within the aforementioned age group because it reduces the risk of falling while performing basic activities of the daily life, such as deviating from people, obstacles and moving quickly to answer the phone or to take a bus. The performance of leg exercises, like plyometric training, leg curl and extension, hip adduction and abduction, running and walking throughout the studies, practiced at least 2 to 3 times a week, for 12 weeks of intervention, maybe the reason why the participants showed an increase in leg strength revealed by the test "sit and stand up" (Figure 2). Leg strength is considered an important factor in what comes to reducing the risk of falling in daily activities such as sitting and standing up from a chair for a meal or walking to the bank or to the supermarket.

Walking, running, and lateral movements are applied to improve the agility of elderly women. When the leg strength is increased, we recommend plyometric training, leg curl/extension, and hip adduction/abduction from 2 to 3 times a week, at least for 12 weeks in order to achieve the results obtained in both tests.

Three years ago, Reichert, Prado, Kanitz, Kruel ${ }^{41}$ conducted a meta-analysis, which showed a substantial increase in all of the outcomes herein studied: leg strength, biceps strength, agility, and posterior muscle chain extensibility. The main differences in favor of the present meta-analysis concerning to the one by Reichert, Prado, Kanitz, Kruel ${ }^{41}$ were four.(1) A larger number of participants in both the control and hydrogymnastics groups; (2) The first was exclusively composed of RCT studies, while the latter included two studies that were not randomized and one that did not have inactive control;(3) All the participants were women, whereas in Reichert, Prado, Kanitz, Kruel ${ }^{41}$ three of the studies included male participants; (4)the inclusion of two RCT studies, Mazini Filho, Macedo Vianna, de Oliveira Venturini, de Matos, Caputo Ferreira $^{30}$ and Moreira, Lopes, Mazini-Filho, Aidar, da Silva Fernandes, de Oliveira Patrocinio ${ }^{32}$, with weights above $14,7 \%$ and 10,2\%,respectively, which were not taken into consideration in Reichert, Prado, Kanitz, Kruel ${ }^{41}$ for chronological matters.

A possible explanation for the fact that the practice of hydrogymnastics has not affected the biceps strength and the posterior muscle chain extensibility in this meta-analysis is the lack of specific exercises for these physical qualities. Among the five studies ${ }^{28-32}$ analyzed, Alves, Mota, Costa, Alves ${ }^{28}$ and Tsourlou ${ }^{31}$ did not have a record of the type of exercise performed. The three other studies, Bocalini, Serra, Murad, Levy ${ }^{29}$, Filho, Macedo Vianna, de Oliveira Venturini, de Matos, Caputo Ferreira ${ }^{30}$ and Moreira, Lopes, Mazini-Filho, Aidar, da Silva Fernandes, de Oliveira Patrocinio ${ }^{32}$ enlisted the physical exercises performed in the trial, but they did not include specific exercises to improve biceps strength nor posterior muscle chain extensibility.

The battery of tests performed by Rikli and Jones ${ }^{37-39}$ presents the classification of functional capacity and/or risk of functional loss for six outcomes ${ }^{37-39}$, however, the studies included in the present meta-analysis have completed the functional capacity assessment for only two to five outcomes, which characterizes them as segmented assessments. All the studies included did not assess the responses to aerobic capacity and shoulder flexibility tests for only one of them performed the complete battery of tests.

The relevance of the aerobic capacity assessment is associated with a higher risk of falls, and the absence of shoulder flexibility is a limiting factor for daily activities such as getting dressed. It leads to functional dependency, especially when other ineffective physical valences are present ${ }^{42}$. The use of the complete Rikli Jones test to assess the functional capacity can contribute to developing the applied physical training, as well as obtaining the functional loss risk.

There are few studies on this matter - only 5 out of the 887 recovered studies were used. It suggests the need for further investigations into the efficacy of the practice of hydrogymnastics over the functional autonomy of elderly women and it also contributed to the low evidence level of the results. In addition to that, the low methodological quality of the RCT studies - all of which scored 1 due to the inadequate randomized allocation for the groups and the lack of blinding - the suspicious of publication bias for the outcomes (Figures 6, 7, 8, and 9) and a high ${ }^{28}$ and uncertain ${ }^{28-32}$ risks of bias of the five studies included (Table 2) contributed to the low level of evidence of this meta-analysis (Board 3). However, the outcomes of the present work resulted from a comprehensive search on the main databases related to the Science of Exercise (Figure 1). Besides that, the present meta-analysis counted on the independent assessment of two researchers on the stages of the search, selection, methodological quality, risk of bias and evidence level. The limitations found in the studies do not overlap to the lack of scientific literature related to the theme, thus reinforcing the relevance of the outcomes of this meta-analysis in order to clarify the efficacy of the practice of hydro gymnastics over the functional capacity of elderly women to the present moment. 


\section{Conclusion}

Hydrogymnastics seems to be an effective tool for Physical Education professionals when it comes to increasing the agility and leg strength of elderly women. Otherwise, the modality did not affect the posterior muscle chain extensibility and biceps strength due to the absence of specific exercises aimed to improve such physical qualities.

Therefore, we suggest that new studies should be carried out, as long as they use the complete battery of tests to combine all the variables to provide the prognosis of the functional capacity and the risk of functional loss among the senior population and, especially, that these new studies bring specific exercises for each trainable physical quality of the functional capacity.

\section{References}

1. de Queiroz BTD, de Oliveira AR, do Carmo Eulálio M. Discapacidad y envejecimiento: estudio de las representaciones sociales de los ancianos de la rehabilitación de terapia física. APL. 2014;33(1):121-33

2. Junior P, Pereira E, Silva ITd, Vilela ABA, Casotti CA, Pinto FJM, et al. Functional dependency and associated factor in elderly living with relatives. Cad Saud Col. 2016;24(4):404-12

3. Valença TDC, Santos WdS, Lima PV, Santana EdS, Reis LAd. Physical disability in old age: a structural study of social representations. Esc Anna Nery. 2017;21(1)

4. Dantas E, Pereira S, Aragão J, Ota A. Perda da flexibilidade no Idoso-A prepoderância da diminuição da mobilidade articular ou da elasticidade muscular na perda da flexibilidade no envelhecimento. JFitn and Perfor Journal. 2002;1(3):12-20

5. Mattos M, Farinatti P. Influência do treinamento aeróbio com intensidade e volume reduzidos na autonomia e aptidão físico-funcional de mulheres idosas. Rev Portg Ciên Desp. 2007;7(1):100-8

6. Jeronimo DP, de Souza FP, da Silva LR, Teodoro PH. Avaliação da autonomia funcional de idosas fisicamente ativas e sedentárias. RevBras Ciên Envel Hum. 2012;8(2)

7. dos Santos Amorim PR, Moura BP, Moreira OC, Marins JCB. Efeito hipotensor de uma sessão de exercícios aquáticos: variabilidade e reprodutibilidade. Rev Bras Ciên Mov. 2009;17(2)

8. de Araújo Alencar N, de Souza Júnior JV, Aragão JCB, de Assunção Ferreira M, Dantas E. Nível de atividade física, autonomia funcional e qualidade de vida em idosas ativas e sedentárias. Fisio Mov. 2017;23(3)

9. Fechine BRA, Trompieri N. O processo de envelhecimento: as principais alterações que acontecem com o idoso com o passar dos anos. Inter Science Place. 2015;1(20)

10. Demográfico IC. Instituto Brasileiro de Geografia e Estatística. Acesso em. 2010;4(01):2011

11. Cordeiro J, Del Castillo BL, Freitas CSd, Gonçalves MP. Effects of physical activity in declarative memory, functional capacity and quality of life in elderly. Rev Bras Geria Geront. 2014;17(3):541-52

12. Maciel, MG. Physical activity and function in elderly. J. Phys. Ed. 2010; 16(4):1024-1032, :

13. Monteiro MdF, Sobral Filho DC. Exercício físico e o controle da pressão arterial. Revista Brasileira de Medicina do Esporte. 2004:513-9
14. Matsudo SM, Matsudo VKR, Neto TLB. Efeitos benéficos da atividade física na aptidão física e saúde mental durante o processo de envelhecimento. Rev Bras Atv Fís \& Saú 2012;5(2):60-76

15. Fiedler MM, Peres KG. Capacidade funcional e fatores associados em idosos do Sul do Brasil: um estudo de base populacional Functional status and associated factors among the elderly in a southern Brazilian city: a population. Cad Saud Pub. 2008;24(2):409-15

16. Seemann T, Schmitt CW, Guimarães ACdA, Korn S, Simas JPN, Souza MdC, et al. Trainability and reversibility in physical fitness among elderly persons taking part in an intervention program. RevBras de Geria Geronto. 2016;19(1):129-37

17. de Oliveira DV, Araújo APS, Bertolini SMMG. Cognitive and functional ability of elderly women practitioners of different modalities of exercise.J Nortt Net Nurs2015;16(6)

18. Da Silva AG, Ribeiro JC. Hidroginástica na terceira idade. Rev Divul Cient. 2012;17(2):49-59

19. Schoenell M, Bgeginski R, Kruel L. Efeitos do treinamento em meio aquático no consumo de oxigênio máximo de idosos: revisão sistemática com metanálise de ensaios clínicos randomizados. Rev Bras Atv Fís \& Sau. 2017;21(6):525-33

20. Miyoshi T, Shirota T, Yamamoto S-I, Nakazawa K, Akai M. Effect of the walking speed to the lower limb joint angular displacements, joint moments and ground reaction forces during walking in water. J Disabil Rehabil. 2004;26(12):724-32

21. Asar S, Jalalpour S, Ayoubi F, Rahmani M, Rezaeian M. Prisma; Preferred Reporting Items for Systematic Reviews and MetaAnalyses. JRUMS. 2016; 15(1):65-80

22. Jadad AR, Moore RA, Carroll D, Jenkinson C, Reynolds DJM, Gavaghan DJ, et al. Assessing the quality of reports of randomized clinical trials: is blinding necessary? Controlled clinical trials. 1996;17(1):1-12

23. De Carvalho A, Silva V, Grande A. Avaliação do risco de viés de ensaios clínicos randomizados pela ferramenta da colaboração Cochrane. RevDiag Tratam. 2013;18(1):38-44

24. Guyatt GH, Oxman AD, Montori V, Vist G, Kunz R, Brozek J, et al. GRADE guidelines: 5 . Rating the quality of evidence-publication bias. J clin epid. 2011;64(12):1277-82

25. Guyatt GH, Oxman AD, Kunz R, Woodcock J, Brozek J, Helfand $\mathrm{M}$, et al. GRADE guidelines: 7. Rating the quality of evidenceinconsistency. J o clin epid. 2011;64(12):1294-302

26. Guyatt GH, Oxman AD, Kunz R, Woodcock J, Brozek J, Helfand $\mathrm{M}$, et al. GRADE guidelines: 8 . Rating the quality of evidenceindirectness. J clin epid. 2011;64(12):1303-10

27. Kulig M, Perleth M, Langer G, Meerpohl JJ, Gartlehner G, Kaminski-Hartenthaler A, et al. GRADE guidelines: 6. Rating the quality of evidence-imprecision. Zeitschrift für Evidenz, Fortbildung und Qualität im Gesundheitswesen. 2012;106(9):677-88

28. Alves RV, Mota J, Costa MdC, Alves JGB. Aptidão física relacionada à saúde de idosos: influência da hidroginástica. Rev Bras Med Esporte. 2004;10(1):31-7

29. Bocalini DS, Serra AJ, Murad N, Levy RF. Water-versus land-based exercise effects on physical fitness in older women. Geria geront inter. 2008;8(4):265-71

30. Mazini Filho ML, Macedo Vianna J, de Oliveira Venturini GR, de Matos DG, Caputo Ferreira ME. Avaliação de diferentes programas de exercícios físicos na força muscular e autonomia funcional de idosas. Motri. 2016;12 
31. Tsourlou T, Benik A, Dipla K, Zafeiridis A, Kellis S. The effects of a twenty-four-week aquatic training program on muscular strength performance in healthy elderly women. JStr Cond Res. 2006;20(4):811

32. Moreira OC, Lopes G, Mazini-Filho M, Aidar F, da Silva Fernandes $\mathrm{S}$, de Oliveira Patrocinio C. Impact of two hydrogymnastics class methodologies on the functional capacity and flexibility of elderly women. J J sports med phys Fitn and p f 2017; 59(1):126-131

33. Vaz ELS, Acciari HA, Assis A, Codaro EN. Uma experiência didática sobre viscosidade e densidade. Química Nova na Escola. 2012;34(3):155-8 http://hdl.handle.net/11449/134959>.

34. Carregaro RL, Toledo AMd. Efeitos fisiológicos e evidências científicas da eficácia da fisioterapia aquática. Rev movim. 2008;1(1):23-27

35. Miyasike-da-Silva V, Villar R, Zago AS, Polastri PF, Gobbi S. Nível de agilidade em indivíduos entre 42 e 73 anos: efeitos de um programa de atividades físicas generalizadas de intensidade moderada. RevBras Cie Esp. 2002;23(3)

36. Plowman SA, Smith DL. Fisiologia do exercício para saúde, aptidão e desempenho. $2^{\circ}$ ED. Rio de Janeiro, Guanabara Koogan, 2000.

37. Jones CJ, Rikli RE. Measuring functional. J Active Aging Jacaging. 2002; $1: 24-30$

38. Rikli RE, Jones CJ. Senior fitness test manual. $2^{\circ} \mathrm{ED}$, Calofornia. Human Kinetics, 2013.

39. Rikli RE, Jones CJ. Development and validation of a functional fitness test for community-residing older adults. J Aging Phy Act. 1999;7(2):129-61
40. Guimarães JMN, Farinatti PdTV. Análise descritiva de variáveis teoricamente associadas ao risco de quedas em mulheres idosas. Rev Bras Med Esp. 2005;11(5):299-305

41. Reichert T, Prado A, Kanitz A, Kruel L. Efeitos da hidroginástica sobre a capacidade funcional de idosos: metanálise de estudos randomizados. Rev Bras de Atv Fís \& Saúde 2015;20(5):447

42. Chodzko-Zajko WJ, Proctor DN, Singh MAF, Minson CT, Nigg CR, Salem GJ, et al. Exercise and physical activity for older adults. Med \& sci sport \& exer. 2009;41(7):1510-30.

\section{Corresponding author}

Ravini de Souza Sodré

R. Ewbank da Câmara, 90 - Madureira, Rio de Janeiro - RJ, 21310-150 Email: ravin.sodre@outlook.com

Manuscript received on June 3, 2019

Manuscript accepted on August 17, 2019

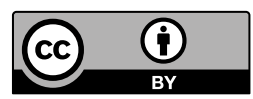

Motriz. The Journal of Physical Education. UNESP. Rio Claro, SP, Brazil - eISSN: 1980-6574 - under a license Creative Commons - Version 4.0 


\section{ANNEXES}

Annex 1. Stages of the Search Strategy.

\begin{tabular}{|c|c|c|c|}
\hline Data base & Search phrase & Filters & Address \\
\hline MEDLINE & 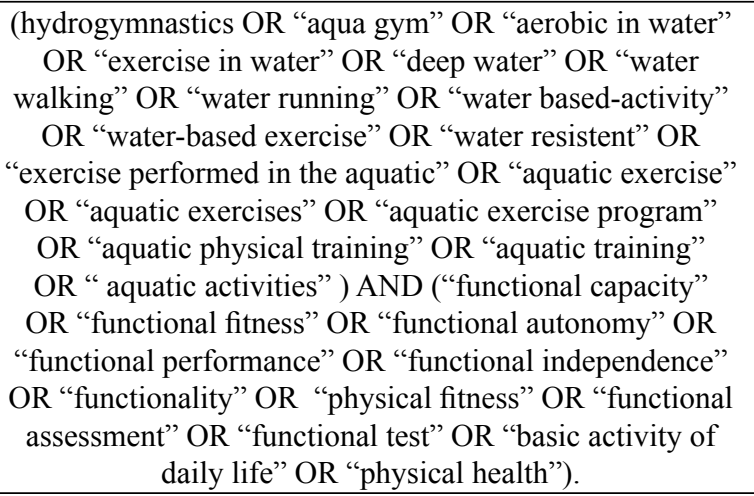 & $\begin{array}{l}\text { Experimental studies. } \\
\text { Humans. Women, over } \\
60 \text { years. }\end{array}$ & www.ncbi.nlm.nih.gov \\
\hline PEDro & $\begin{array}{l}\text { functional capacity AND aerobic in water; functional } \\
\text { capacity AND exercise in water; functional capacity AND } \\
\text { water walking; functional capacity AND water-based } \\
\text { exercise; functional capacity AND exercise performed in } \\
\text { the aquatic; functional capacity AND aquatics exercise; } \\
\text { functional capacity AND aquatic exercise program. }\end{array}$ & $\begin{array}{l}\text { Experimental studies. } \\
\text { Humans. Women, over } \\
60 \text { years. }\end{array}$ & http://www.search.pedro.org.au \\
\hline SciELO & hydrogymnastics AND functional capacity & $\begin{array}{c}\text { Experimental studies. } \\
\text { Humans. Women, over } \\
60 \text { years. } \\
\end{array}$ & http://www.search.scielo.org \\
\hline $\begin{array}{l}\text { Web of } \\
\text { Science }\end{array}$ & $\begin{array}{l}\text { Hydrogymnastics AND functional capacity; Activity } \\
\text { aquatic AND functional capacity; }\end{array}$ & $\begin{array}{l}\text { Experimental studies. } \\
\text { Humans. Women, over } \\
60 \text { years. }\end{array}$ & http://www.capes.gov.br/ \\
\hline CINAHL & Hydrogymnastics AND functional capacity & $\begin{array}{l}\text { Experimental studies. } \\
\text { Humans. Women, over } \\
60 \text { years. }\end{array}$ & http://www.capes.gov.br/ \\
\hline SPORTDiscus & Hydrogymnastics AND functional capacity & $\begin{array}{l}\text { Experimental studies. } \\
\text { Humans. Women, over } \\
60 \text { years. }\end{array}$ & http://www.capes.gov.br/ \\
\hline SCOPUS & $\begin{array}{l}\text { Hydrogymnastics; hydrogymnastic AND functional } \\
\text { capacity; Exercise Aquatic AND functional capacity }\end{array}$ & $\begin{array}{l}\text { Experimental studies. } \\
\text { Humans. Women, over } \\
60 \text { years. }\end{array}$ & http://www.capes.gov.br/ \\
\hline $\begin{array}{l}\text { The Cochrane } \\
\text { Library }\end{array}$ & $\begin{array}{l}\text { hydrogymnastics OR exercise in water AND functional } \\
\text { capacity OR functional autonomy }\end{array}$ & $\begin{array}{c}\text { Experimental studies. } \\
\text { Humans. Women, over } \\
60 \text { years. } \\
\end{array}$ & http://www.onlinelibrary.wiley.com \\
\hline LILACS & Hydrogymnastics AND functional capacity & $\begin{array}{l}\text { Experimental studies. } \\
\text { Humans. Women, over } \\
60 \text { years. }\end{array}$ & http://lilacs.bvsalud.org/ \\
\hline
\end{tabular}

